\title{
Ruthenium-doped Titania-pillared Clay for The Selective Catalytic Oxidation of Cyclohexene: Influence of Ru Loading
}

\author{
Ahmed Dali ${ }^{1,2}$, Ilhem Rekkab-Hammoumraoui ${ }^{*}$, Sanaa El Korso ${ }^{1}$, Souheyla Boudjema ${ }^{1,2}$, \\ Abderrahim Choukchou-Braham ${ }^{1}$ \\ ${ }^{1}$ Laboratory of Catalysis and Synthesis in Organic Chemistry, Faculty of Science at \\ AbouBakr Belkaïd University - P.O.Box 119 - Tlemcen 13000, Algeria. \\ ${ }^{2}$ Faculty of Hydrocarbons, Renewable Energy, Earth Sciences and Universe, Kasdi Merbah University, \\ Ouargla 30000, Algeria.
}

Received: 22 $2^{\text {nd }}$ April 2019; Revised: $11^{\text {th }}$ July 2019; Accepted: $16^{\text {th }}$ July 2019; Available online: 30th September 2019; Published regularly: December 2019

\section{Abstract}

A series of ruthenium-based catalysts supported on acid-activated montmorillonite (PILC) and interspersed with titanium (Ru/Ti-PILCs) were prepared with various amounts of ruthenium. Their catalytic performances in the selective oxidation of cyclohexene, using tert-butylhydroperoxide (TBHP) as oxidant were checked. The clay structure modification by acid activation and impregnation of transition metals resulted in an enhanced Lewis and Bronsted acidities. The Ru/Ti-PILCs materials were characterized using X-ray diffraction (XRD), surface area and pore volume measurements, surface acidity followed by Fourier transform infrared (FTIR) spectroscopy, chemical analysis, and Scanning Electron Microscopy (SEM). It was found that all catalysts can selectively oxidize cyclohexene through allylic oxidation leading mainly to 2-cyclohexene-1-one (Enone) as the major product, and 2-cyclohexene-1-ol (Enol) as secondary product. With the $5 \% \mathrm{Ru} / \mathrm{Ti}$-PILC, it was possible to reach $59 \%$ cyclohexene total conversion, and $87 \%$ selectivity into 2-cyclohexene-1-one and $13 \%$ selectivity into 2-cyclohexene-1-ol. Copyright $@ 2019$ BCREC Group. All rights reserved

Keywords: Cyclohexene; Pillared clay; Ruthenium; Selective oxidation; TBHP

How to Cite: Dali, A., Rekkab-Hammoumraoui, I., El Korso, S., Boudjema, S., Choukchou-Braham, A. (2019). Ruthenium-doped Titania-pillared Clay for The Selective Catalytic Oxidation of Cyclohexene: Influence of $\mathrm{Ru}$ Loading. Bulletin of Chemical Reaction Engineering \& Catalysis, 14(3): 614-624 (doi:10.9767/bcrec.14.3.4723.614-624)

Permalink/DOI: https://doi.org/10.9767/bcrec.14.3.4723.614-624

\section{Introduction}

Clays are polyvalent materials that may be employed in various applications, ranging from ceramics to catalysts. Their wide utilization is mainly due to their properties, such as acidity, surface nature and/or their composition [1,2]. It is worth reminding that in catalysis; only the

* Corresponding Author.

E-mail: ahmed2lcsc@gmail.com external surface of the material is active, as large organic molecules cannot dodge in and out layers. Moreover, though non-polar molecules have reduced dimensions, they cannot penetrate into the material due to the hydrophilic character of the layers [3]. In order to obtain thermally stable materials with a greater interlayer distance, cations can be intercalated between the clay layers. These cations act as pillars that help in keeping the silicate layers separated, even in the absence of solvents. 
Pillared clays are prepared by exchanging the charge compensating cations, which are normally found in the interfoliary space of the parent clay, with bulky polycations obtained by hydrolysis of chosen metal salts. Upon heating, these polyoxocations undergo structural transformations and are decompose into metal oxyhydroxide clusters, called pillars, which maintain the clay layers apart thus precluding their collapse. The resulting material is stable, with acidic character. It also presents a porous structure generated by the intercalation of the interfoliary space [4-9]. A variety of oxides, such as: $\mathrm{Al}_{2} \mathrm{O}_{3}$ [10], $\mathrm{ZrO}_{2}$ [11], $\mathrm{TiO}_{2}$ [11], $\mathrm{Fe}_{2} \mathrm{O}_{3}$ [12], $\mathrm{SnO}_{2}$ and mixed oxides, like $\mathrm{SiO}_{2}-\mathrm{Fe}_{2} \mathrm{O}_{3}$, $\mathrm{SiO}_{2}-\mathrm{TiO}_{2}$ [13], $\mathrm{TiO}_{2}-\mathrm{ZrO}_{2}$ [14], and $\mathrm{Fe}_{2} \mathrm{O}_{3}-\mathrm{TiO}_{2}$ [15], have been successfully employed to get pillared clays. The pillared clays are generally known to be stable up to a temperature range of $500-700^{\circ} \mathrm{C}$.

In addition to supporting the layers, the metal oxide pillars contribute to the acidity of the material. This involves the generation of structures with both Bronsted and Lewis acidities, which may influence the composition of the products obtained in organic catalytic reactions. The acidity of the obtained material is greater than that of the initial clay or parent clay [16]. The increase in the clay's acidy is ascribed to two factors: first, the larger specific surface area of the clay, as compared to that of non-pillared clay and, second, the appearance of new acid sites on pillars and in the sites existing between the clay layers and pillars. The Bronsted acidity is associated with the liberation of protons during the dehydroxylation of the pillars and the clay sheets, while the Lewis acidity is attributed to the metal oxide pillars. The strength and number of sites of both acids are directly related to the nature of clays and pillars [17].

The allylic oxidation of alkenes is an important and useful reaction in many industries [18]. The allylic oxidation of cyclohexene has been the subject of many papers in recent years [19- 25] and many catalysts, such as: nitrogendoped carbon nanotubes (N-CNTs) [26], $\mathrm{VO}_{2-}$ $\mathrm{SiO}_{2}$ [27], mixed oxides $(\mathrm{Ru} / \mathrm{Co} / \mathrm{Ce})$ [28], zeolite$\mathrm{Y}$ entrapped transition metal complexes [29], manganese porphyrins [30], PdO/SBA-15 [31], Fe-MIL-101 and Metal-organic frameworks MIL-101(Cr) [32], have been studied.

Up to now, the cases of catalytic allylic oxidation of cyclohexene in the presence of clays or pillared clays have been uncommon and, to the best of our knowledge, $\mathrm{RuO}_{2}$ has not been used in the cyclohexene oxidation reactions, although $\mathrm{Ru}$ complexes have been extensively used in a large number of epoxidation reactions, among which are the epoxidation of propene, octene, cyclohexene, cyclooctene, styrene, etc. [33,34]. Thus, and for the first time, we considered it interesting to evaluate the supported- $\mathrm{RuO}_{2}$ catalytic oxidation of cyclohexene.

The fact that PILCs present an acidic character and have a porous structure makes them interesting and efficient supports for catalytic applications. Earlier, our group has performed some studies on the preparation, characterization of ruthenium impregnate $\mathrm{H}$ Montmorillonite (H-Mont) and Ti-pillared clay (Ti-PILC) for cyclohexene oxidation with tertbutylhydroperoxide (TBHP) as oxidant [35]. In continuation of these works, we have prepared and characterized $1-3 \mathrm{wt} \% \mathrm{Ru} / \mathrm{Ti}$-PILC to be tested in the oxidation reaction. The final aim of this complementary study is to gather all results obtained by our group in order to highlight the mechanism of cyclohexene oxidation.

\section{Materials and Method}

2.1 Ruthenium Supported Ti-pillared Montmorillonite Synthesis

Ti-PILC was prepared following the procedure proposed by Bineesh et al. [36] and described in our early work [35]. The used raw montmorillonite comes from the town of Maghnia (Western Algeria). Its basal spacing is $1.44 \mathrm{~nm}$ and its $S_{\text {BET }}$ is $195 \mathrm{~m}^{2} / \mathrm{g}$. Its cation exchange capacity is 0.34 meq per/g. The Ti-PILC supported $\mathrm{Ru}$ catalysts were prepared by the conventional wet impregnation process, in acetone suspensions, in order to obtain materials containing 1 to $3 \mathrm{wt} \%$ of ruthenium. $\mathrm{Ru}(\mathrm{acac})_{3}$ was used as the precursor salt. The obtained solids were dried for $72 \mathrm{~h}$ at $60{ }^{\circ} \mathrm{C}$, and then calcined under atmospheric air for $4 \mathrm{~h}$ at 240 ${ }^{\circ} \mathrm{C}$. This was performed with the heating rate of $3{ }^{\circ} \mathrm{C} \cdot \mathrm{min}^{-1}$ [37].

\subsection{Measurements}

The amount of $\mathrm{Ru}$ in the prepared catalysts was determined by means of a Perkin Elmer AA300 Flame Atomic Absorption Spectrophotometer. The pre-processing was carried out by acid dissolution. The X-ray powder diffraction (XRD) patterns were obtained using a Rigaku D/max 2500 powder X-ray diffractometer with a Cu Ka radiation $(\lambda=1.541874 \AA)$ in the range $2 \theta=2-70^{\circ}$, with a step of $0.02^{\circ}$ and an acquisition time of $1 \mathrm{~s}$.

The Micromeritics Quantachrome NOVA 1000 instrument analyzer was used to determine the adsorption-desorption isotherms at 
$77 \mathrm{~K}$. Prior to measurements, the samples were outgassed at $250{ }^{\circ} \mathrm{C}$ for $3 \mathrm{~h}$. The specific areas were estimated according to the BrunauerEmmett-Teller (BET) equation.

The FTIR spectra of the solid samples were recorded using an Agilent Technologies Cary 640 spectrometer. FTIR analysis of chemisorbed pyridine was conducted on an Agilent Technologies Cary 640 spectrometer equipped with an ATR accessory in order to determine the acidic properties of the samples. Measurements were carried out following the procedure described in a previous work [38]. SEM Micrographies were collected on a HitachiTM.1000 at a $150 \mathrm{KV}$ acceleration voltage, coupled with EDX analysis (energy-dispersive Xrays).

\subsection{Catalytic Evaluation of Solids}

The oxidation reaction of cyclohexene with tert-butylhydroperoxide TBHP (70 wt.\% in $\mathrm{H}_{2} \mathrm{O}$, Aldrich) as oxidant was carried out in a $100 \mathrm{~mL}$ three neck glass round bottom flask fitted with a water condenser, magnetic stirrer and thermometer. Initially, $5.5 \mathrm{~mL} \quad(38.45$ mmol) of oxidant were mixed to $25 \mathrm{~mL}$ of heptane (solvent) and stirred for $24 \mathrm{~h}$ in a closed Erlenmeyer flask. This operation was performed in order to achieve a phase transfer of TBHP from water to organic phase. The organic phase was then isolated from the aqueous one. An iodometric titration was performed to control the concentration of the remaining TBHP in the aqueous phase $(<10 \%$ of initial TBHP). A glass reactor was then charged with

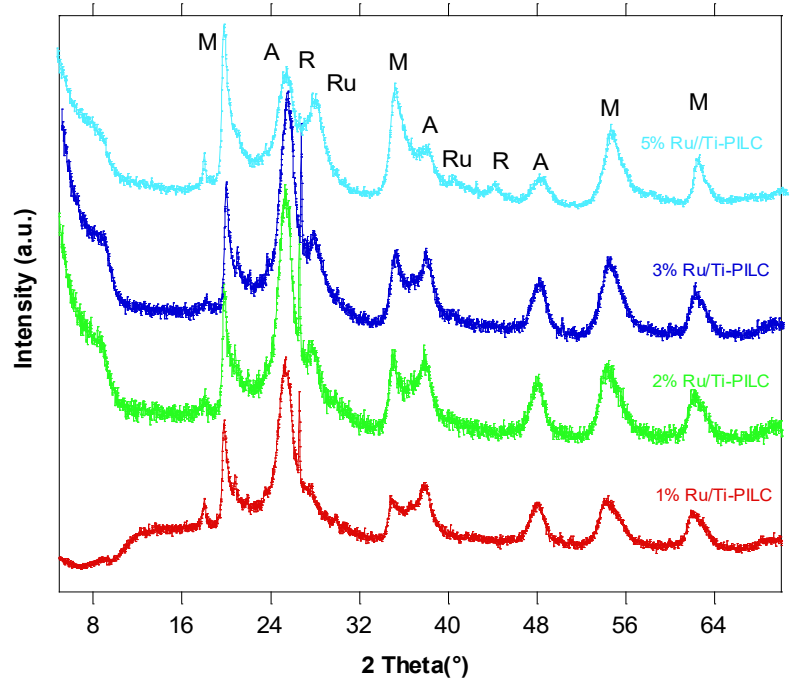

Figure 1. XRD patterns of the supported materials (M: Montmorillonite; A: Anatase; R: Rutile; $\mathrm{Ru}: \mathrm{RuO}_{2}$ ) the organic phase (TBHP-heptane mixture), 29 mmol $(3 \mathrm{~mL})$ of cyclohexene and $0.1 \mathrm{~g}$ of catalyst, heated under vigorous stirring at $70{ }^{\circ} \mathrm{C}$ during $6 \mathrm{~h}$. The reaction products were analyzed by gas chromatography (GC), using a GC6500-YL-Instrument system equipped with an Agile HP-FFAP capillary column and a flame ionization detector (FID). The remaining TBHP was analyzed at the end of the reaction (after 6 h), by iodometric titration. The conversion, the selectivity of products and the turnover frequency were calculated using the following equations:

$$
\begin{aligned}
& \text { Conversion }(\%)=\frac{[\text { Cyclohexene }]_{0}-[\text { Cyclohexene }]_{t}}{[\text { Cyclohexene }]_{0}} \times 100 \\
& \text { Selectivity }(\%)=\frac{(\text { Moles of } \text { individual product })}{(\text { Moles of total products })} \times 100 \\
& \operatorname{TOF}\left(h^{-1}\right)=\frac{(\text { Moles of products })}{(\text { Moles of catalysts }) \times(\text { time })}
\end{aligned}
$$

\section{Results and Discussion}

\subsection{Characterization of Samples}

The XRD patterns of ( $x=1-5$ wt \%) Ru/TiPILC are shown in Figure 1. The twodimensional diffractions hk of PILCs located at $19.8^{\circ}$ and $35.8^{\circ}$ are characteristic of montmorillonite (for Ti-PILC $\mathrm{d}_{001}$ is observed at $2 \theta=3.3^{\circ}$ related to the basal spacing of $2.67 \mathrm{~nm}$ ) [35]. The first diffraction is the sum of the indexes hk of (02) and (11), while the last one is the sum of the indexes hk (13) and (20). Moreover, the reflections at $2 \theta=25^{\circ}, 38^{\circ}, 48^{\circ}$ and $53^{\circ}$ are observed for anatase-titanium (JCPDS: 21-

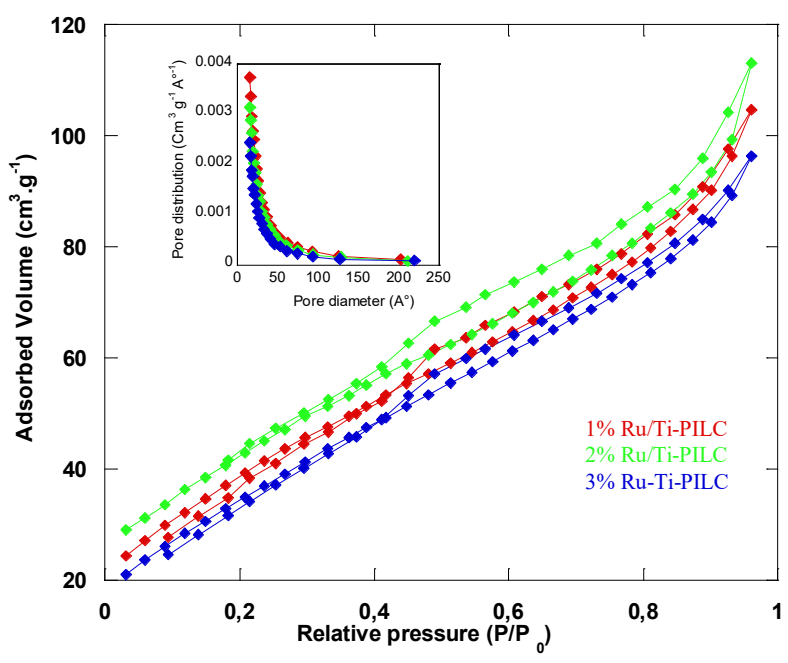

Figure 2. $\mathrm{N}_{2}$ adsorption-desorption isotherms and BJH-pore size distribution of the supported samples 
1272) [39]. The appearance of peaks at $2 \theta=28^{\circ}$ and $35^{\circ}$ suggests the presence of ruthenium oxide in our materials (JCPDS: 40-1290). With the increase of $\mathrm{Ru}$ content, the anatase peaks intensities gradually decrease and the rutile appears at $2 \theta=27^{\circ}, 36^{\circ}$ and $41^{\circ}$ (JCPDS: 21 1276), even when the Ru content reaches $3 \%$.

The $\mathrm{N}_{2}$ adsorption-desorption isotherms and pore size distributions of Ti-PILC and the supported catalysts are displayed in Figure 2. The isotherms data of 1,2 and $3 \% \mathrm{Ru}$ Ti-PILC catalysts are type VI isotherms (Figure 2), with an $\mathrm{H} 4$ type hysteresis loop following the IUPAC classification [40]. This type of isotherms is characteristic of the presence of mesopores. The hysteresis indicates the presence of micropores as well. Insert of the Figure 2 shows that the BJH pore size distribution of all samples presents a unimodal and narrow peak, centred at $15 \AA$. However, an increase in the ruthenium oxide loading onto the Ti-PILC support ( $\mathrm{S}_{\mathrm{BET}}=$ $278 \mathrm{~m}^{2} \cdot \mathrm{g}^{-1}$ ) [35] decreased the surface area, probably because of pore blockade resulting from their progressive filling with ruthenium species (Table 1) [41- 43].

Figure 3 shows the FTIR spectra of 1,2 , and $3 \%$ Ru/Ti-PILC materials. The FTIR spectrum of materials exhibits two bands at 3642 and $3448 \mathrm{~cm}^{-1}$ in the $-\mathrm{OH}$ stretching region. These

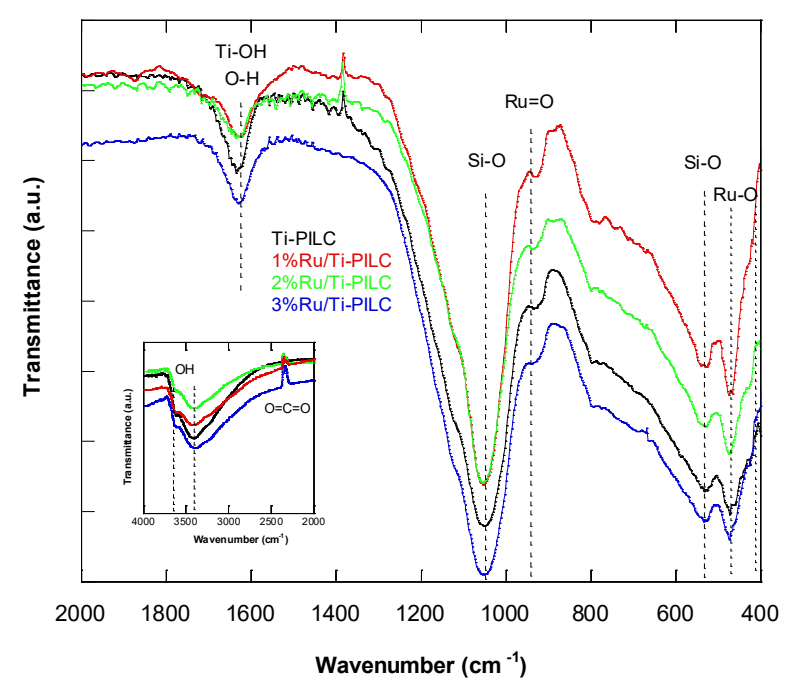

Figure 3. FTIR spectra of the supported materials bands are attributed to the clay structural hydroxyl groups and water molecules in the interlayers [42,44].

The band around $1600 \mathrm{~cm}^{-1}$ is attributed to the bending vibrations of water and $\mathrm{Ti}-\mathrm{OH}$ [45]. The strong band around $1040 \mathrm{~cm}^{-1}$ is characteristic of the asymmetric stretching vibrations of tetrahedral $\mathrm{SiO}_{2}$ [46]. The band at 524 $\mathrm{cm}^{-1}$ can be ascribed to the $\mathrm{Si}-\mathrm{O}$ bending vibrations. On the other hand, the absorptions observed at $442,430,428 \mathrm{~cm}^{-1}$ [47], and also around $668 \mathrm{~cm}^{-1}$ [48] represent the $\mathrm{Ru}-\mathrm{O}$ groups. The peak detected at $980 \mathrm{~cm}^{-1}$ correspond to the $\mathrm{Ru}=\mathrm{O}$ peak $[49,50]$. The bands at 1457, 1540, and $2903 \mathrm{~cm}^{-1}$ were observed for ruthenium supported catalysts. They can be assigned to the presence of $-\mathrm{C}=\mathrm{C},-\mathrm{C}=\mathrm{O}$, and $\mathrm{C}-\mathrm{H}$ groups, respectively. However, these bands were not observed in purified clay or pillared clay, which suggests that the acetylacetonate salt was not completely removed from the supported samples after calcinations.

The infrared (IR) spectroscopy in the region from 1400 to $1600 \mathrm{~cm}^{-1}$ was carefully checked, in order to study the pyridine adsorption on the clay surface in order to better determine the acidity of the clay. The band at $1450 \mathrm{~cm}^{-1}$ can be attributed to Lewis acid sites (Lpy) [51] and the band at $1540 \mathrm{~cm}^{-1}$ is due to Bronsted acid sites (Bpy) [52]. The concentrations of Lewis and Bronsted acid sites were calculated from the integrated intensities of the Bpy and Lpy bands (1450 and $1540 \mathrm{~cm}^{-1}$ ) and the values of the molar absorption coefficients of these

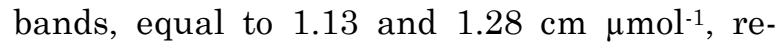
spectively, as previously determined by Guisnet et al. [53] while studying the sorption of given amounts of pyridine on $\mathrm{H}$-mordenite (containing only Bronsted sites) and on alumina (containing only Lewis sites). The results obtained are shown in Table 2. They indicate that the number of Lewis acid sites is distinctly higher than that of Bronsted acid sites for TiPILC. Data from the literature on Ti-PILC indicate the presence of both Lewis and Bronsted acidities, with the Lewis acid being more dominant [54]. In general, the pillaring of clay causes a considerable increase in acidity. This in-

Table 1. Textural properties and metal content of the samples

\begin{tabular}{lccc}
\hline & $1 \% \mathrm{Ru} / \mathrm{Ti}$-PILC & $2 \% \mathrm{Ru} / \mathrm{Ti}$-PILC & $3 \% \mathrm{Ru} / \mathrm{Ti}$-PILC \\
\hline $\mathrm{Ru}$ loading $(\%)$ & 0.95 & 1.87 & 2.86 \\
$S_{\text {BET }}\left(\mathrm{m}^{2} \cdot \mathrm{g}^{-1}\right)$ & 248 & 238 & 226 \\
$V_{\mathrm{p}}\left(\mathrm{cm}^{3} \cdot \mathrm{g}^{-1}\right)$ & 0.30 & 0.31 & 0.35 \\
$d_{\mathrm{p}}(\AA)$ & 15 & 15 & 19 \\
\hline
\end{tabular}




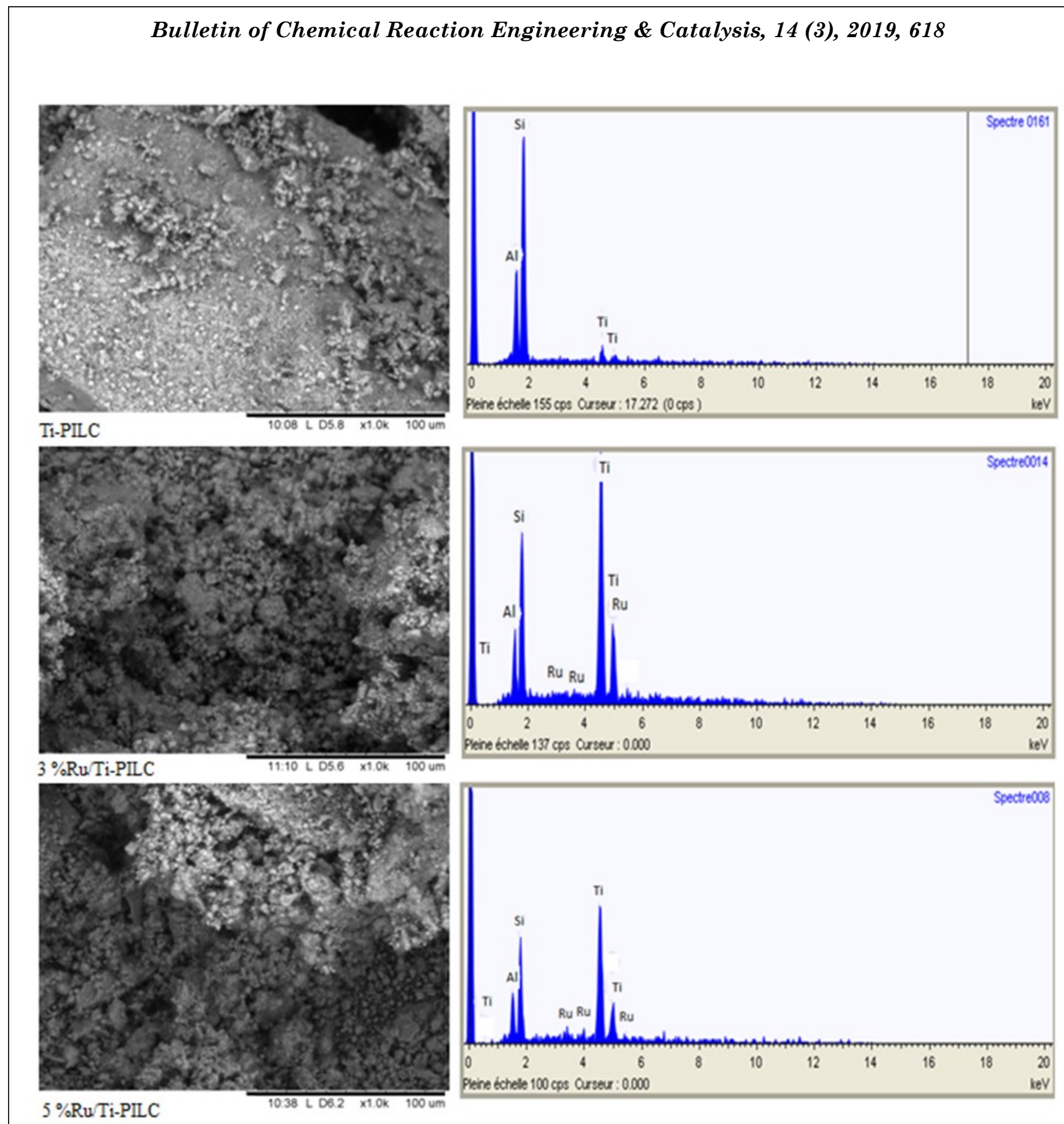

Figure 4. SEM micrographs and EDX analysis of Ti-PILC, 3 \%Ru/Ti-PILC and 5 \%Ru/Ti-PILC materials

Table 2. Lewis and Bronsted acidity ( $\left.\mu \mathrm{mol} . \mathrm{g}^{-1}\right)$ of Ti-PILC and its supported Ru materials upon adsorption of pyridine

\begin{tabular}{lcccc}
\hline \multicolumn{1}{r}{ Catalyst } & $\begin{array}{c}\text { Lewis acid sites } \\
\text { (Lpy) } \\
\mu \text { mol.g-1 }\end{array}$ & $\begin{array}{c}\text { Bronsted acid sites } \\
(\text { Bpy) } \\
\mu \text { mol.g-1 }\end{array}$ & $\begin{array}{c}\text { Lpy }+ \text { Bpy } \\
\mu m o l . g-1\end{array}$ & {$[$ Lpy]/[ Bpy] } \\
\hline Ti-PILC & 260 & 87 & 347 & 2.98 \\
$1 \%$ Ru/Ti-PILC & 186 & 93 & 279 & 2.00 \\
$3 \%$ Ru/Ti-PILC & 300 & 105 & 405 & 2.85 \\
$5 \%$ Ru/Ti-PILC & 434 & 116 & 550 & 3.74 \\
\hline
\end{tabular}


elsewhere [35]. The best catalytic performance previously reported is $5 \% \mathrm{Ru} / \mathrm{Ti}$-PILC, which presents a conversion of $59 \%$ with $89 \%$ and 11 $\%$ selectivities for 2-cyclohexene-1-one 2 - and cyclohexene-1-ol, respectively. In comparison to other reports presented in the literatures (Tables 4 and 5), it can be established that this catalyst $5 \% \mathrm{Ru} / \mathrm{Ti}$-PILC is the most interesting one. It is worth mentioning that incorporating $\mathrm{TiO}_{2}$ into clay could further enhance the catalyst activity and products selectivity. Qadir et al. [58] indicated that $\mathrm{TiO}_{2}$ was able to boost the cyclohexene oxidation to yield cyclohexen-1one and cyclohexen-1-ol. Layered clays have been extensively used as acid catalysts and as supports alike. IR spectroscopy has been utilized to prove that the metal oxide pillars are responsible for the Lewis acidity; the Bronsted acid sites are located on the clay sheets [59]. As a conclusion, one may therefore say that
Bronsted and Lewis acid sites in PILC are effective in catalysing the oxidation of cyclohexene, as this can be explained by the Mars and van Krevelen mechanism [59]. Additionally, using TBHP as oxidant under the conditions of an acid catalyst enhances the allylic oxidation pathway, while decreasing the epoxidation [60]. Several mechanisms of cyclohexene oxidation are much debated in the literature and many intermediate complexes are suggested [27,61-63].

Based on our experimental observations and literature reports, a mechanism of cyclohexene oxidation, catalysed by the materials $\mathrm{Ru} / \mathrm{Ti}$-PILC developed in the present article, is described in Scheme 1, according to which the initial complex combination of metal catalyst and tert-butyl hydroperoxide makes peroxidic oxygen more electrophilic and hence more labile to attack by an olefinic double bond. Then

Table 5. A summary of the catalysts used in the literature for the oxidation of cyclohexene

\begin{tabular}{|c|c|c|c|c|c|c|c|c|}
\hline \multirow{2}{*}{ Catalyst } & \multirow{2}{*}{ Substrate } & \multirow{2}{*}{$\begin{array}{c}\text { Conversion } \\
(\%)\end{array}$} & \multicolumn{5}{|c|}{ Selectivity (\%) } & \multirow{2}{*}{ Ref. } \\
\hline & & & Enol & Enone & Epoxide & Diol & One & \\
\hline Ti-PILC & $\begin{array}{l}\text { Cyclohexene, TBHP as } \\
\text { oxidant, heptane as sol- } \\
\text { vent, } 70^{\circ} \mathrm{C}, 6 \mathrm{~h}, 0.1 \mathrm{~g} \\
\text { catalyst }\end{array}$ & 26 & 89 & 11 & 0 & 0 & 0 & [35] \\
\hline $5 \% \mathrm{Ru} / \mathrm{Ti}$-PILC & $\begin{array}{l}\text { Cyclohexene, TBHP as } \\
\text { oxidant, heptane as sol- } \\
\text { vent, } 70^{\circ} \mathrm{C}, 6 \mathrm{~h}, 0.1 \mathrm{~g} \\
\text { catalyst }\end{array}$ & 59 & 13 & 87 & 0 & 0 & 0 & [35] \\
\hline $6 \% \mathrm{~V} / \mathrm{Fe}-\mathrm{Mont}$ & $\begin{array}{l}\text { Cyclohexene, TBHP as } \\
\text { oxidant, heptane as sol- } \\
\text { vent, } 70^{\circ} \mathrm{C}, 6 \mathrm{~h}, 0.1 \mathrm{~g} \\
\text { catalyst }\end{array}$ & 87 & 3 & 7 & 67 & 7 & 16 & [12] \\
\hline $15 \% \mathrm{~V} / \mathrm{Cr}-\mathrm{AAC}$ & $\begin{array}{l}\text { Cyclohexene, TBHP as } \\
\text { oxidant, heptane as sol- } \\
\text { vent, } 70^{\circ} \mathrm{C}, 6 \mathrm{~h}, 0.05 \mathrm{~g} \\
\text { catalyst }\end{array}$ & 38.3 & 2 & 4.4 & 65 & 10.3 & 18.3 & [64] \\
\hline Au/monolith & $\begin{array}{l}\text { Cyclohexene, TBHP as } \\
\text { oxidant, acetonitrile as } \\
\text { solvent, } 30^{\circ} \mathrm{C}, 6 \mathrm{~h}, 0.05 \\
\text { g catalyst }\end{array}$ & 18.3 & 16 & 81.5 & 2.5 & 0 & 0 & [56] \\
\hline $\mathrm{Ru} / \mathrm{CeO}_{2}$ & $\begin{array}{l}\text { Cyclohexene, TBHP as } \\
\text { oxidant, } 1,2- \\
\text { dichloroethane as sol- } \\
\text { vent, } 60{ }^{\circ} \mathrm{C}, 12 \mathrm{~h}, 0.005 \mathrm{~g} \\
\text { catalyst }\end{array}$ & 38.1 & 40.5 & 49.6 & 5.7 & 0 & 4.2 & [65] \\
\hline $\mathrm{RuC1}_{2}(4-\mathrm{Mepy})_{4}$ & $\begin{array}{l}\text { Cyclohexene, CHP } \\
\text { (cumenehydroperoxide) } \\
\text { as oxidant, THF as sol- } \\
\text { vent, } 50{ }^{\circ} \mathrm{C}, 5 \text { h, } 2.910^{-5} \\
\text { mole catalyst }\end{array}$ & - & 48.7 & 51.7 & 0 & 0 & 0 & [66] \\
\hline $\mathrm{Co}_{3} \mathrm{O}_{4}$ & $\begin{array}{l}\text { Cyclohexene, TBHP as } \\
\text { oxidant, heptane as sol- } \\
\text { vent, } 70^{\circ} \mathrm{C}, 6 \mathrm{~h}, 0.1 \mathrm{~g} \\
\text { catalyst }\end{array}$ & 78 & 43 & 41 & 0 & 0 & 16 & [67] \\
\hline
\end{tabular}


crease is due to the intercalation and presence of metal oxide pillars [54].

The addition of ruthenium oxide to Ti-PILC increased more significantly the number of Lewis acid sites, comparatively to Bronsted acid sites. Furthermore, a strong increase in the total acidity was observed when moving from the starting Ti-PILC to the supported Tipillared materials. Based on the infrared spectra of adsorbed pyridine, Sorlino et al. [55] concluded that ruthenium oxide ions display a rather strong Lewis acidity on the face of $\mathrm{RuO}_{2}$. Bronsted acids involve $\mathrm{OH}$ groups.

The ratio of the numbers of Lewis vs Bronsted sites is also presented in Table 2. It can be seen that this ratio increases gradually as the ruthenium loading rises. This may be due to the weak interaction of $\mathrm{RuO}_{2}$ with the support, which facilitates the access of the single pair of free electrons from ruthenium oxide to the clay surface. The studied samples can thus be ordered with respect to the number of acid sites as follows: $5 \% \mathrm{Ru} / \mathrm{Ti}$-PILC $>3$ $\%$ Ru/Ti-PILC $>1 \%$ Ru/Ti-PILC $>$ Ti-PILC.

The SEM micrographs coupled with EDX analysis are presented in Figure 4. Ti-PILC micrograph shows large particles with smooth surfaces coexisting with fine grains probably $\mathrm{TiO}_{2}$. Whereas, micrographs of the supported

Table 3. EDX analysis results of Ti-PILC, $3 \% \mathrm{Ru} / \mathrm{Ti}-\mathrm{PILC}$, and $5 \% \mathrm{Ru} / \mathrm{Ti}-\mathrm{PILC}$ materials

\begin{tabular}{lccc}
\hline Component & $\begin{array}{c}\text { Ti-PILC } \\
\text { (wt.\%) }\end{array}$ & $\begin{array}{c}3 \% \mathrm{Ru} / \mathrm{Ti}- \\
\text { (wt.\%) }\end{array}$ & $\begin{array}{c}5 \% \mathrm{Ru} / \mathrm{Ti}- \\
\text { (wt.\%) }\end{array}$ \\
\hline $\mathrm{SiO}_{2}$ & 28.30 & 25.75 & 22.44 \\
$\mathrm{Al}_{2} \mathrm{O}_{3}$ & 12.82 & 11.91 & 14.37 \\
$\mathrm{TiO}_{2}$ & 58.88 & 59.55 & 58.99 \\
$\mathrm{RuO}_{2}$ & 0 & 2.79 & 4.20 \\
\hline
\end{tabular}

Ti-pillared materials shows a homogeneous distribution of small grains covering completely the clay surface [56]. EDX microanalysis shows the structural elements of clay, namely silicon and aluminum. The presence of $\mathrm{TiO}_{2}$ indicated the existence of pillars in the clay. The ruthenium loadings of catalysts $3 \% \mathrm{Ru} / \mathrm{Ti}$-PILC and $5 \% \mathrm{Ru} / \mathrm{Ti}$-PILC were determined to 2.79 wt.\% Ru and 4.18 wt.\% Ru, respectively (see Table 3).

\subsection{Catalytic Oxidation of Cyclohexene}

Cyclohexene oxidation with tert-butyl hydroperoxide (TBHP) over the studied materials gives several products, following two pathways: (i) the oxidation at the allylic position yielding 2-cyclohexene-1-ol (Enol), 2-cyclohexene-1-one (Enone), cyclohexanol (Ol), cyclohexanone (One), and (ii) the oxidation of the double bound, resulting in cyclohexane oxide (Epoxide) and cyclohexane diols (Diol). Table 3 sums up all the catalytic results of cyclohexene oxidation over the catalysts. No oxidation product was obtained in the absence of catalysts [32].

In all catalytic experiments, it was found that the cyclohexene conversion increases with the ruthenium content from $18 \%$ with a turnover frequency (TOF) of $88 \mathrm{~h}^{-1}$ over $1 \% \mathrm{Ru} / \mathrm{Ti}$ PILC to $44 \%$ and a TOF of $72 \mathrm{~h}^{-1}$ over $3 \% \mathrm{Ru} / \mathrm{Ti}$-PILC. The oxidation reaction preferentially happened within the activated allylic $\mathrm{C}-\mathrm{H}$ bond, which led to the selective products 2-cyclohexene-1-one and 2-cyclohexene-1-ol. In fact, the selectivity for 2-cyclohexene-1-ol decreased from $61 \%$ to $39 \%$, and the selectivity for 2-cyclohexene-1-one increased from $39 \%$ to $60 \%$. This may be due to the fact that Ru/TiPILC, which has strong Lewis acid sites (Table 2), favors the formation of Enone [57].

The oxidation of cyclohexene with TBHP in the presence of $5 \% \mathrm{Ru} / \mathrm{Ti}$-PILC was studied

Table 4. Cyclohexene oxidation using different supported catalysts

\begin{tabular}{|c|c|c|c|c|c|c|c|c|c|}
\hline \multirow[b]{2}{*}{ Catalyst } & \multicolumn{2}{|c|}{ Activity } & \multicolumn{6}{|c|}{ Selectivity (\%) } & \multirow{2}{*}{$\begin{array}{c}\text { TBHP } \\
\text { Consumptior } \\
(\%)\end{array}$} \\
\hline & $\begin{array}{c}\text { Conversion } \\
(\%)\end{array}$ & $\begin{array}{l}\text { TOF } \\
\left(\mathrm{h}^{-1}\right)\end{array}$ & Enol & Enone & Epoxide & Diol & One & $\mathrm{Ol}$ & \\
\hline Blank & 0 & 1 & 0 & 0 & 0 & 0 & 0 & 0 & 0 \\
\hline $1 \% \mathrm{Ru} / \mathrm{Ti}-\mathrm{PILC}$ & 18 & 88 & 61 & 39 & 0 & 0 & 0 & 0 & 43 \\
\hline $2 \% \mathrm{Ru} / \mathrm{Ti}-\mathrm{PILC}$ & 42 & 103 & 42 & 58 & 0 & 0 & 0 & 0 & 44 \\
\hline $3 \% \mathrm{Ru} / \mathrm{Ti}$-PILC & 44 & 72 & 39 & 60 & 0 & 0 & 0 & 0 & 40 \\
\hline $5 \% \mathrm{Ru} / \mathrm{Ti}$-PILC & 59 & 58 & 13 & 87 & 0 & 0 & 0 & 0 & 73 \\
\hline
\end{tabular}

$C_{6} H_{12}=3 \mathrm{~mL} ; \mathrm{TBHP}=5.5 \mathrm{~mL} ;$ solvent $=25 \mathrm{~mL} ;$ catalyst $=0.1 \mathrm{~g} ; t=6 \mathrm{~h} ; \mathrm{T}=70^{\circ} \mathrm{C}$;

TOF $=$ mole of converted cyclohexene per unit time per mole of dispersed ruthenium. 
the anion ${ }^{\mathrm{t}} \mathrm{BuO}-$, resulting from the reaction that occurs in parallel to the complex attacks on the $\mathrm{C} 6$ ring, leading to the formation of an unsaturated alcohol which undergoes a new oxidation reaction that gives cyclohexenone. The radical mechanism happens especially in the presence of $\mathrm{H}_{2} \mathrm{O}_{2}$ or $\mathrm{O}_{2}$ as oxidant. Both of these reagents are known to generate free radicals [68-70].

\section{Conclusions}

The goal of the present work was to develop clay-based materials to be used as green catalysts in the reaction of cyclohexene oxidation. Both Lewis and Bronsted acid sites were evidenced in these catalysts, as determined by the FT-IR analysis. It was shown herein that the acid sites guided the reaction towards allylic oxidation. The addition of ruthenium to the titanium-pillared clay enhanced the activity of pillared clay significantly. In the presence of 5 $\% \mathrm{Ru} / \mathrm{Ti}-\mathrm{PILC}$ catalyst, cyclohexene was converted in $59 \%$, to primarily 2 -cyclohexen-1-one (selectivity $=87 \%$ ) and to 2 -cyclohexen-1-ol as a by-product, in the presence of TBHP, at the temperature of $70{ }^{\circ} \mathrm{C}$. The oxidation of cyclohexene was really heterogeneous and no ruthenium leaching was observed.

\section{Conflicts of interest}

There are no conflicts to declare.

\section{Acknowledgements}

The authors gratefully acknowledge the financial support provided by the General Direction for Scientific and Technological Research (DGRST) as well as the Thematic Research Agency for Science and Technology (ATRST), for the project PNR-8-U13-880. The authors also thank Pr. S. Bedrane from LCSCO for her valuable help in revising the manuscript.

\section{References}

[1] Murray, H.H. (2000). Traditional and new applications for kaolin, smectite, and palygorskite: a general overview. Applied Clay Science, 17: 207-221.

[2] Vaccari, A. (1999). Clays and catalysis: a promising future. Applied Clay Science, 14: 161-98.

[3] Dal Bosco, S.M., Jimenez, R.S., Vignado, C., Fontana, J., Geraldo, B., Figueiredo, F.C.A., Mandelli, D., Carvalho, W.A. (2006). Removal of $\mathrm{Mn}(\mathrm{II})$ and $\mathrm{Cd}(\mathrm{II})$ from wastewaters by natural and modified clays. Adsorption, 12: 133-146.

[4] Gil, A., Gandia, L.M., Vicente M.A. (2000). Recent Advances in the Synthesis and Catalytic Applications of Pillared Clays. Catalysis Review, 42: 145-212.

[5] Vaccari, A. (1998). Preparation and catalytic properties of cationic and anionic clays. $\mathrm{Ca}$ talysis Today, 41: 53 -71.

[6] Vaughan, D.E.W. (1988). Pillared clays - A historical perspective. Catalysis Today, 2: 187-98.

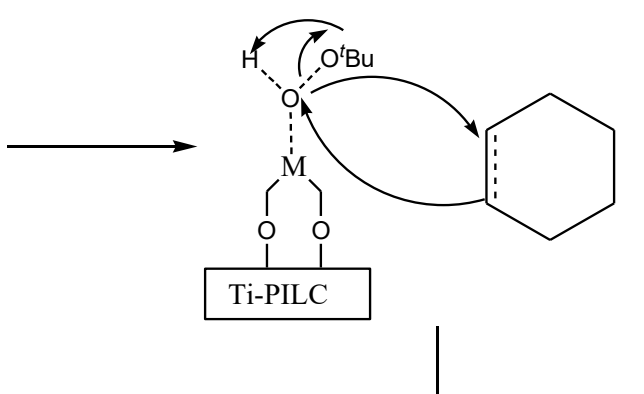

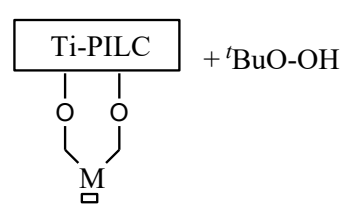
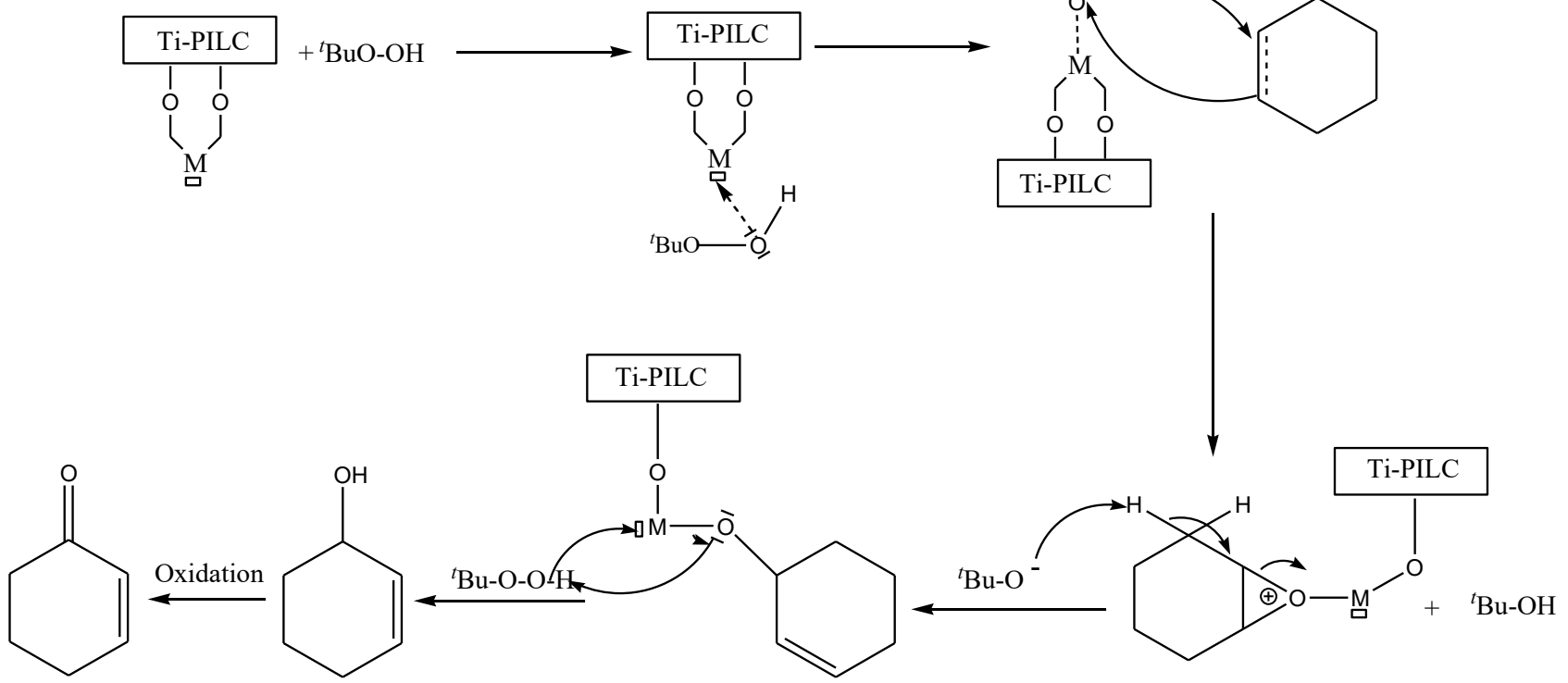

Scheme 1. Proposed mechanism for Ru/Ti-PILC oxidation of cyclohexene to 2-cyclohexen-1-ol and 2cyclohexen-1-one 
[7] Figueras, F. (1988). Pillared Clays as Catalysts. Catalysis Review, 30: 457-499.

[8] Lambert, J.F., Poncelet, G. (1997). Acidity in pillared clays: origin and catalytic manifestations. Topics in Catalysis, 4: 43-56.

[9] Pinnavaia, T.J. (1983). Intercaled Clay Catalysts. Science, 220: 365-371.

[10] Basoglu, F.T., Balci, S. (2016). Catalytic properties and activity of copper and silver containing Al-pillared bentonite for CO oxidation. Journal of Molecular Structure, 1106: 382-389.

[11] Bineesh, K.V., Kim, D.K., Cho, H.J., Park D.W. (2010). Synthesis of metal-oxide pillared montmorillonite clay for the selective catalytic oxidation of $\mathrm{H}_{2} \mathrm{~S}$. Journal of Industrial and Engineering Chemistry, 16: 593-597.

[12] Brahimi, S., Boudjema, S., Rekkab, I., Choukchou-Braham, A., Bachir, R. (2015). Synthesis and Catalytic Activity of Vanadia-Doped IronPillared Clays for Cyclohexene Epoxidation. Research Journal of Pharmaceutical, Biological and Chemical Sciences, 6: 63-76.

[13] Chmielarz, L., Kowalczyk, A., Wojciechowska, M., Boroń, P., Dudek, B., Michalik, M. (2014). Montmorillonite intercalated with $\mathrm{SiO}_{2}, \mathrm{SiO}_{2}$ $\mathrm{Al}_{2} \mathrm{O}_{3}$ or $\mathrm{SiO}_{2}-\mathrm{TiO}_{2}$ pillars by surfactantdirected method as catalytic supports for DeNOx process. Chemical Paper, 68: 12191227.

[14] Bahranowski, K., Włodarczyk, W., WisłaWalsh, E., Gaweł, A., Matusik, J., Klimek, A., Gil, B., Michalik-Zym, A., Dula, R., Socha, R.P., Serwicka, E.M. (2015). [Ti,Zr]-pillared montmorillonite - A new quality with respect to Ti- and Zr-pillared clays. Microporous Mesoporous Materials, 202: 155-164.

[15] Tomul, F., Basoglu, F.T., Canbay, H. (2016). Determination of adsorptive and catalytic properties of copper, silver and iron contain titanium-pillared bentonite for the removal bisphenol A from aqueous solution. Applied Surface Science, 360: 579-593.

[16] Occelli, M.L., Tindwa, R.M. (1983). Physicochemical properties of montmorilloniteinterlayed with cationic oxyaluminumpilllars. Clays and Clay Minerals, 31: 22-28.

[17] Zhao, D., Yang, Y., Guo, X. (1995). Synthesis and characterization of hydroxy-CrAI pillared clays. Zeolites, 15: 58-66.

[18] Jiang, D., Mallat, T., Meier, D.M., Urakawa, A., Baiker, A. (2010). Copper metal-organic framework: Structure and activity in the allylic oxidation of cyclohexene with molecular oxygen. Journal of Catalysis, 270: 26-33.

[19] Parra da Silva, F., Gonçalves, R.V., Rossi, L.M. (2017). Magnetically recoverable copper oxide catalysts for aerobic allylic oxidation of cyclohexene. Journal of Molecular Catalysis A: Chemical, 426: 534-541.

[20] Rekkab-Hammoumraoui, I., Khaldi, I., Choukchou-Braham, A., Bachir, R. (2013). $\mathrm{TiO}_{2}-\mathrm{SiO}_{2}$ mixed oxides: Xerogel catalyst for the Selective Epoxidation of cyclohexene. Research Journal of Pharmaceutical, Biological and Chemical Sciences, 4: 935-946.

[21] Driss, L., Choukchou-Braham, A., Kappenstein, C., Pirault-Roy, L. (2012). Synthesis, characterization and activity in cyclohexene epoxidation of $\mathrm{V}_{2} \mathrm{O}_{5}-\mathrm{TiO}_{2}$ anatasexerogel. Journal of Sol-Gel Science and Technology, 64: 637-642.

[22] Ameur, N., Bedrane, S., Bachir, R., Choukchou-Braham., A. (2013). Influence of nanoparticles oxidation state in gold based catalysts on the product selectivity in liquid phase oxidation of cyclohexene. Journal of Molecular Catalysis A: Chemical, 374-375: 16.

[23] EL-Korso, S., Rekkab, I., ChoukchouBraham, A., Bedrane, S., Pirault-Roy, L.,Kappenstein, C. (2012). Synthesis of vanadium oxides 5 wt. $\% \mathrm{VO}_{2}-\mathrm{M}_{\mathrm{x}} \mathrm{O}_{\mathrm{y}}$ by sol-gel process and application in cyclohexene epoxidation. Bulletin of Material Science, 35: 11871194.

[24] El-Korso, S., Bedrane, S., ChoukchouBraham, A., Bachir, R. (2015). The effect of redox properties of ceria-supported vanadium oxides in liquid phase cyclohexene oxidation. RSC Advances, 5: 63382-63392.

[25] Hakat, Y., Kotbagi, T.V., Bakker, M.G. (2016). Silver supported on hierarchically porous $\mathrm{SiO}_{2}$ and $\mathrm{Co}_{3} \mathrm{O}_{4}$ monoliths: Efficient heterogeneous catalyst for oxidation of cyclohexene. Journal of Molecular Catalysis A: Chemical, 411: 61-71.

[26] Cao, Y., Yu, H., Wang, H., Peng, F. (2017). Solvent effect on the allylic oxidation of cyclohexene catalyzed by nitrogen doped carbon nanotubes. Catalysis Communications, 88: 99-103.

[27] El-Korso, S., Khaldi, I., Bedrane, S., Choukchou-Braham, A., Thibault-Starzyk, F., Bachir, R. (2014). Liquid phase cyclohexene oxidation over vanadia based catalysts with tert-butyl hydroperoxide: Epoxidation versus allylic oxidation. Journal of Molecular Catalysis A: Chemical, 394: 89-96.

[28] Ghiaci, M., Aghabarari, B., Botelho do Rego, A.M., Ferraria, A.M., Habibollahi, S. (2011). Efficient allylic oxidation of cyclohexene catalyzed by trimetallic hybrid nano-mixed oxide (Ru/Co/Ce). Applied Catalysis A: General, 393: 225-230.

[29] Godhani, D.R., Nakum, H.D., Parmar, D.K., Mehta, J.P., Desai, N.C. (2016). Tuning of the 
reaction parameters to optimize allylic oxidation of cyclohexene catalyzed by zeolite-Y entrapped transition metal complexes. Journal of Molecular Catalysis A: Chemical, 415: 3755.

[30] Rutkowska-Zbik, D., Witko, M., Serwicka, E.M. (2011). Allylic oxidation of cyclohexene catalyzed by manganese porphyrins: DFT studies. Catalysis Today,169: 10-15.

[31] Ganji, S., Bukya, P., Vakati, V., Rao, K.S.R., Burri, D.R. (2013). Highly efficient and expeditious $\mathrm{PdO} / \mathrm{SBA}-15$ catalysts for allylic oxidation of cyclohexene to cyclohexenone. Catalysis Science \& Technology, 3: 409-414.

[32] Skobelev, I.Y., Sorokin, A.B., Kovalenko, K.A., Fedin, V.P., Kholdeeva, O.A. (2013). Solventfree allylic oxidation of alkenes with $\mathrm{O}_{2}$ mediated by $\mathrm{Fe}$ - and Cr-MIL-101. Journal of Catalysis, 298:61-69.

[33] Chatterjee, D., Basak, S., Mitra, A., Sengupta, A., Le Bras, J., Muzart, J. (2005). Synthesis and catalytic activity of a novel ruthenium(III) complex containing a sugarbased ligand. Catalysis Communications, 6: 459-461.

[34] de Souza, V.R., Nunes, G.S., Rocha, R.C., Toma, H.E. (2003). Spectroscopy, electrochemistry and catalytic properties of ruthenium II complexes containing the tetradentate Schiff base ligand N, $\mathrm{N}^{\prime}$-bis (7-methyl-2pyridylmethylene)-1,3-diiminopropane. Inorganica Chimica Acta, 348: 50-56.

[35] Dali, A., Rekkab-Hammoumraoui, I., Choukchou-Braham, A., Bachir, R. (2015). Allylic oxidation of cyclohexene over ruthenium-doped titanium-pillared clay. RSC Advances, 5: 29167-29178.

[36] Bineesh, K.V., Kim, D.K., Kim, M.I.L., Park, D.W. (2011). Selective catalytic oxidation of $\mathrm{H} 2 \mathrm{~S}$ over $\mathrm{V}_{2} \mathrm{O}_{5}$ supported on $\mathrm{TiO}_{2}$-pillared clay catalysts in the presence of water and ammonia. Applied Clay Science, 53: 204-211.

[37] Bernas, A., Kumar, N., Laukkanen, P., Vayrynen, J., Salmi, T., Murzin, D.Y. (2004). Influence of ruthenium precursor on catalytic activity of $\mathrm{Ru} / \mathrm{Al}_{2} \mathrm{O}_{3}$ catalyst in selective isomerization of linoleic acid to cis-9,trans-11- and trans-10,cis-12-conjugated linoleic acid. $A p$ plied Catalysis A: General, 267: 121-33.

[38] Rekkab-Hammoumraoui, I., ChoukchouBraham, A., Pirault-Roy, L., Kappenstein, C. (2011). Catalytic oxidation of cyclohexane to cyclohexanone and cyclohexanol by tert-butyl hydroperoxide over Pt/oxide catalysts. Bulletin of Material Science, 34: 1127-1135.

[39] Romero, A., Dodorado, F., Asencio, I., Garcia, P.B., Valverde, J.L. (2006). Ti-pillared clays: synthesis and general characterization. Clays and Clay Minerals, 54:737-747.
[40] Brunauer, S., Deming, L.S., Deming, W.E., Teller, E. (1940). Theory of the van der Waals adsorption of gases. Journal of American Chemical Society, 62: 1723-1732.

[41] Kim, M., Lee, G., Kim, D.W., Kang, D.H., Park, D.W. (2014). Production of elemental sulfur and ammonium thiosulfate by $\mathrm{H}_{2} \mathrm{~S}$ oxidation over $\mathrm{Nb}_{2} \mathrm{O}_{5}$ supported on Fe-pillared clay. Korean Journal of Chemical Engineering, 31: 2162-2169.

[42] Bineesh, K.V., Kim, D.K., Kim, D.W., Cho, H.J., Park, D.W. (2010). Selective catalytic oxidation of $\mathrm{H}_{2} \mathrm{~S}$ to elemental sulfur over $\mathrm{V}_{2} \mathrm{O}_{5} / \mathrm{Zr}$-pillared montmorillonite clay. Energy \& Environmental Science, 3: 302-310.

[43] Sahel, K., Bouhent, M., Belkhadem, F., Ferchichi, M., Dappozze, F., Guillard, C., Figueras, F. (2014). Photocatalytic degradation of anionic and cationic dyes over $\mathrm{TiO}_{2}$ P25, and Ti-pillared clays and Ag-doped Tipillared clays. Applied Clay Science, 95: 205210.

[44] Binitha, N.N., Sugunan, S. (2006). Preparation, characterization and catalytic activity of titania pillared montmorillonite clays. $M i$ croporous and Mesoporous Materials, 93:,8289.

[45] Poppl, L., Toth, E., Toth, M., Paszli, I., Izvekov, V., Gabor, M. (1998). Synthesis and Characterizations of hydroxy-Aluminum cross-linked montmorillonite. Journal of Thermal Analysis, 53: 585-596.

[46] Carriazo, J.G., Moreno-Forero, M., Molina, R.,A., Moreno, S. (2010). Incorporation of titanium and titanium-iron species inside a smectite-type mineral for photocatalysis. $A p$ plied Clay Science, 50: 401-408.

[47] Kannan, S.K., Sundrarajan, M. (2015). Green synthesis of ruthenium oxide nanoparticles: Characterization and its antibacterial activity. Advanced Powder Technology, 26: 15051511.

[48] Jeng, J.S., Lin, Y.T., Chen, J.S. (2010) Preparation and characterization of transparent semiconductor $\mathrm{RuO}_{2}-\mathrm{SiO}_{2}$ films synthesized by sol-gel route. Thin Solid Films, 518: 54165420 .

[49] Ismail, A.A., Bahnemann, D.W., Al-Sayari, S.A. (2012). Synthesis and photocatalytic properties of nanocrystalline $\mathrm{Au}, \mathrm{Pd}$ and Ptphotodeposited onto mesoporous $\mathrm{RuO}_{2}$ $\mathrm{TiO}_{2}$ nanocomposites. Applied Catalysis A: General, 431-432:,62-68.

[50] Hosokawa, S., Fujinami, Y., Kanai, H. (2005). Reactivity of $\mathrm{Ru}=\mathrm{O}$ species in $\mathrm{RuO}_{2} / \mathrm{CeO}_{2}$ catalysts prepared by a wet reduction method. Journal of Molecular Catalysis A: Chemical, 240: 49-54. 
[51] Corma, A. (1997). From Microporous to Mesoporous Molecular Sieve Materials and Their Use in Catalysis. Chemical Reviews, 97: 23732419.

[52] Chae, H.J., Nama, I.S., Ham, S., Bong Hong, S. (2001). Physicochemical characteristics of pillared interlayered clays. Catalysis Today, 68: 31-40.

[53] Guisnet, M., Ayrault, P., Coutanceau, C., Alvarez, M.F., Datkac, J. (1997). Acid properties of dealuminated beta zeolites studied by IR spectroscopy. Journal of Chemical Society, Faraday Transactions, 93: 1661-1665.

[54] Bineesh, K.V., Kim, S.Y., Jermy, B.R., Park, D.W. (2009). Synthesis, characterization and catalytic performance of vanadia-doped delaminated zirconia-pillared montmorillonite clay for the selective catalytic oxidation of hydrogen sulfide. Journal of Molecular Catalysis A: Chemical, 308: 150-158.

[55] Sorlino, M., Busca, G. (1984). FT-IR Study of the acid sites on the surface of silica supported ruthenium oxide. Applications of Surface Science, 18: 268-2672.

[56] Alotaibi, M.T., Taylor, M.J., Liu, D., Beaumont, S.K., Kyriakou, G. (2016). Selective oxidation of cyclohexene through gold functionalized silica monolith microreactors. Surface Science, 646: 179-185.

[57] Zhou, J., Cao, S., Yang, X., Chen, Q., Luo, X., Zheng, M. (2017). Highly selective allylic oxidation of cyclohexene over molybdenum-doped manganese oxide catalysts. Reaction Kinetics, Mechanisms and Catalysis, 120: 567-578.

[58] Qadir, M.I., Scholten, J.D., Dupont, J. (2014). $\mathrm{TiO}_{2}$ nanomaterials: Highly active catalysts for the oxidation of hydrocarbons. Journal of Molecular Catalysis A: Chemical, 383-384: 225-230.

[59] Corma, A., Garcıa, H. (2002). Lewis Acids as Catalysts in Oxidation Reactions: From Homogeneous to Heterogeneous Systems. Chemical Reviews, 102: 3837-3892.

[60] Ding, Z., Kloprogge, J.T., Frost, R.L., Lu, G.Q., Zhu, H.Y. (2001). Porous Clays and Pillared Clays-Based Catalysts. Part 2: A Review of the Catalytic and Molecular Sieve Applications. Journal of Porous Materials, 8: 273-293.

[61] Cai, X., Wang, H., Zhang, Q., Tong, J., Lei, Z. (2014). Magnetically recyclable core-shell $\mathrm{Fe}_{3} \mathrm{O}_{4} @$ chitosan-Schiff base complexes as efficient catalysts for aerobic oxidation of cyclohexene under mild conditions. Journal of $\mathrm{Mo}$ lecular Catalysis A: Chemical, 383-384:217224.
[62] Silva, F.P., Jacinto, M.J., Landers, R., Rossi, L.M. (2010). Selective Allylic oxidation of Cyclohexene by a Magnetically Recoverable Cobalt Oxide Catalyst. Catalysis Letters, 141: 432-437.

[63] Jorda, E., Tuel, A., Teissier, R., Kervennal, J. (1998). Synthesis, Characterization, and Activity in the Epoxidation of Cyclohexene with Aqueous $\mathrm{H}_{2} \mathrm{O}_{2}$ of Catalysts Prepared by Reaction of $\mathrm{TiF}_{4}$ with Silica. Journal of Catalysis, 175: 93-107.

[64] Belaidi, N., Bedrane, S., Choukchou-Braham, A., Bachir, R. (2015). Novel vanadiumchromium-bentonite green catalysts for cyclohexene epoxidation. Applied Clay Science, 107: 14-20.

[65] Ghiaci, M., Aghabarari, B., Botelho do Rego, A.M., Ferraria, A.M., Habibollahi, S. (2011). Efficient allylic oxidation of cyclohexene catalyzed by trimetallic hybridnano-mixed oxide (Ru/Co/Ce). Applied Catalysis A: General, 393: 225-230.

[66] Kanmani, A.S., Vancheesan, S. (1998). Oxidation of cyclohexene and styrene catalysed by ruthenium(II) complexesunder homogeneous conditions. Recent Advances in Basic and Applied Aspects of Industrial Catalysis Studies in Surface Science and Catalysis, 113: 285292.

[67] Azzi, H., Rekkab-Hammoumraoui, I., ChérifAouali, L., Choukchou-Braham, A. (2019). Mesoporous $\mathrm{Co}_{3} \mathrm{O}_{4}$ as a New Catalyst for AllylicOxidation of Cyclohexene. Bulletin of Chemical Reaction Engineering \& Catalysis, 14 (1): 112-123.

[68] Canepa, A.L., Chanquia, C.M., Eimer, G.A., Casuscelli, S.G. (2013). Oxidation of olefins employing mesoporous molecular sieves modified with copper. Applied Catalysis A: General, 462-463: 8- 14.

[69] Chanquia, C.M., Canepa, A.L., BazanAguirre, J., Sapag, K., Rodriguez-Castellon, E., Reyes, P., Herrero, E.R., Casuscelli, S.G., Eimer, G.A. (2012). Copper-containing spherical mesoporous silicates prepared by template-ion exchange: A multitechnique characterization and oxidation properties. $\mathrm{Mi}$ croporous and Mesoporous Materials, 151: 212.

[70] Chanquia, C.M., Canepa, A.L., Winkler, E.L., Rodriguez-Castellon, E., Casuscelli, S.G., Eimer, G.A. (2016). Nature of active vanadium nanospecies in MCM-41 type catalysts for olefins oxidation. Materials Chemistry and Physics, 175: 172-179. 